\title{
Is the Right To Organize Unconstitutional?
}

Waremart Foods v. NLRB, 354 F.3d 870 (D.C. Cir. 2004).

Do union organizers have the right to organize on private property? As far as federal law is concerned, the answer to that question is clear. Employee organizers have broad rights under the National Labor Relations Act (NLRA); nonemployee union organizers have virtually none. Until a recent decision by the D.C. Circuit, however, there was little reason to believe that federal law, much less the Constitution, prevented states from granting workplace access rights to nonemployee organizers. While the issue had not been squarely addressed, it seemed safe to assume that state right-to-organize laws were the type of economic regulation subject to highly deferential constitutional review since the end of the Lochner era.

The D.C. Circuit challenged that assumption in Waremart Foods $v$. NLRB (Waremart II). ${ }^{1}$ The court overturned a National Labor Relations Board (NLRB) decision ${ }^{2}$ holding that a nonunion supermarket had engaged in unfair labor practices by attempting to bar union organizers from distributing literature to consumers in the store parking lot. Although California law appeared to protect labor-related leafleting on private property, the D.C. Circuit reasoned that to the extent the state law afforded special protections to labor leafleting, it was content-discriminatory in violation of the First Amendment. ${ }^{3}$ Although the D.C. Circuit did not directly overturn the California law-it instead "construe[d] it to avoid unconstitutionality"4 - at the heart of Waremart II lies the notion that laws expressly protecting labor-related speech violate the First Amendment.

This Comment considers the sweeping implications of Waremart II's First Amendment analysis and takes a far more deferential view of the constitutionality of state labor laws. Part I briefly reviews the rights of nonemployee organizers prior to Waremart II. Part II explores the scope of the D.C. Circuit's opinion, arguing that the court's blunt reasoning calls into question the constitutionality of virtually all right-to-organize laws-

1. 354 F.3d 870 (D.C. Cir. 2004).

2. Waremart Foods (Waremart I), 337 N.L.R.B. 289 (2001), enforcement denied, 354 F.3d 870 .

3. Waremart II, 354 F.3d at 874-75.

4. Id. at 875 . 
including provisions of the NLRA itself. Part III suggests an alternative analysis of the California law that is both more faithful to First Amendment principles and less threatening to state economic regulation.

As currently interpreted by the Supreme Court, federal labor law offers few protections for nonemployee union organizers. The text of the NLRA does not mention nonemployee organizers at all, providing only that "[e]mployees shall have the right to self-organization, to form, join, or assist labor organizations." Although the Court made clear early on that the rights of nonemployees under the NLRA were limited, ${ }^{6}$ the NLRB's interpretations shifted over time, and by the late 1980s nonemployee organizers enjoyed not insignificant rights to organize in private

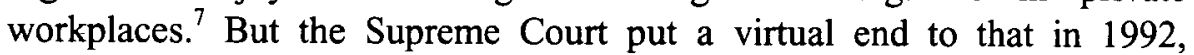
clarifying in Lechmere, Inc. v. NLRB that, "[a]s a rule,"8 the NLRA does not compel private employers to let nonemployee organizers on their property, subject only to very "narrow" exceptions."

First Amendment protection for nonemployee organizing on private property has followed a similar trajectory. In Amalgamated Food Employees Union Local 590 v. Logan Valley Plaza, Inc., the Court held that union organizers had a First Amendment right to picket in privately owned shopping malls. ${ }^{10}$ Only eight years later, however, the Court overruled Logan Valley Plaza in Hudgens v. NLRB and held that "the constitutional guarantee of free expression has no part to play" in cases involving labor picketing at private places of business. ${ }^{11}$

Despite the Court's retreat from a federal right to organize on private property, before Waremart II it appeared that states were free to extend workplace access rights to nonemployee organizers. As the Supreme Court had expressly noted, even after Lechmere nothing in the NLRA guaranteed employers the right to exclude nonemployee organizers from their property; this right came from state property law. ${ }^{12}$ Meanwhile, Lechmere's holding that the NLRA contained virtually no protections for nonemployees seemed

5. National Labor Relations Act $\S 7,29$ U.S.C. $\S 157$ (2000) (emphasis added).

6. See NLRB v. Babcock \& Wilcox Co., 351 U.S. 105, 113 (1956).

7. See Jean Country, 291 N.L.R.B. 11 (1988), abrogated by Lechmere, Inc. v. NLRB, 502 U.S. 527 (1992).

8. 502 U.S. at 533.

9. Id. at 539 (citing Babcock \& Wilcox Co., 351 U.S. at 113).

10. 391 U.S. 308 (1968), abrogated by Hudgens v. NLRB, 424 U.S. 507 (1976).

11. 424 U.S. at 521.

12. Thunder Basin Coal Co. v. Reich, 510 U.S. 200, 217 n.21 (1994) ("The right of employers to exclude union organizers from their private property emanates from state common law, and while this right is not superseded by the NLRA, nothing in the NLRA expressiy protects it."). 
to cut against the notion that state laws granting rights to nonemployees would be preempted by the NLRA. ${ }^{13}$

Before Waremart II, the First Amendment seemed to present even less of a threat to state workplace access laws than did NLRA preemption. In PruneYard Shopping Center v. Robins, the U.S. Supreme Court upheld a California Supreme Court decision holding that the right to leaflet in shopping malls was protected by free speech provisions of the state constitution. ${ }^{14}$ The mall owners argued that California's protection of picketing on private property violated the mall owners' First Amendment rights, compelling them to endorse messages with which they disagreed. The Court was unmoved. As Justice Marshall observed in his concurrence, the ability of states to regulate access to private property beyond the level set by federal law seemed compelled by the negative precedent of Lochner v. New York. ${ }^{15}$ The alternative would be the untenable proposition "that the common law of trespass is not subject to revision by the State." 16

Against this backdrop, the Waremart II court's analysis of California labor law is extraordinary. Below, the NLRB had reasoned that a California statute, the Moscone Act, protected picketing and leafleting related to labor disputes; it thus found that Lechmere did not control, and that it was an unfair labor practice for the supermarket to try to remove the organizers. ${ }^{17}$

13. See NLRB v. Calkins, 187 F.3d 1080, 1095 (9th Cir. 1999) (holding that a California law permitting labor picketing on private property was not preempted by the NLRA). But see Rum Creek Coal Sales, Inc. v. Caperton, 971 F.2d 1148 (4th Cir. 1992) (overturning on preemption grounds a West Virginia law prohibiting police from enforcing trespass laws against striking workers). For an argument that the Supreme Court preemption precedents followed in Calkins, rather than those followed in Rum Creek, should apply to state workplace access laws, see Michael H. Gottesman, Rethinking Labor Law Preemption: State Laws Facilitating Unionization, 7 YALE J. ON REG. 355, 416-18 (1990). In Waremart, the employer made an unsuccessful preemption argument before the NLRB. See Waremart Foods (Waremart I), 337 N.L.R.B. 289, 289 (2001). In overruling the NLRB on other grounds, the D.C. Circuit made no mention of the Board's preemption analysis. See Waremart Foods v. NLRB (Waremart II), 354 F.3d 870 (D.C. Cir. 2004).

14. 447 U.S. 74 (1980) (affirming Robins v. Pruneyard Shopping Ctr., 592 P.2d 341 (Cal. 1979)). Just three years before the California Supreme Court's decision, the U.S. Supreme Court had decided Hudgens, ending federal constitutional protection for picketing in malls. See 424 U.S. 507. California simply retained pre-Hudgens First Amendment law under the state constitution. The state court decision, which remains good law, granted a state constitutional right to leaflet in shopping malls, not in stand-alone supermarkets, and so did not control Waremart II.

15. PruneYard, 447 U.S. at 93 (Marshall, J., concurring) (citing Lochner v. New York, 198 U.S. $45(1905)$ ).

16. Id.

17. Waremart I, 337 N.L.R.B. at 292-93. The Moscone Act bars California courts from enjoining labor picketing. See CAL. CIV. PrOC. CODE $\S 527.3$ (West 1979). Absent a legal right to do so, an attempt to remove union leafleters constitutes interference, restraint, or coercion of the right to organize and form unions. See National Labor Relations Act §8(a)(1), 29 U.S.C. $\S 158(a)(1)(2000)$. 
The D.C. Circuit reversed, holding that the leading California case interpreting the Moscone Act, Sears, Roebuck \& Co.v. San Diego County District Council of Carpenters, ${ }^{18}$ was no longer good law to the extent it "rested on the Moscone Act's special protection for labor activity." ${ }^{19}$ Citing two U.S. Supreme Court cases, Police Department v. Mosley and Carey v. Brown, the court asserted that such special protections "constituted content discrimination in violation of the First Amendment." ${ }^{20}$ If the issue were to arise again, the D.C. Circuit reasoned, California courts would construe the law to avoid unconstitutionality by removing the special protections. It thus held that "under California law labor organizing activities may be conducted on private property only to the extent that California permits other expressive activity to be conducted on private property. $" 21$

Buried within its complex opinion, the D.C. Circuit's brief First Amendment analysis is sweeping. The court assumed that Mosley and Carey squarely controlled, and thus made little attempt to articulate what in particular it was about the protection of labor-related consumer handbilling that violated the First Amendment. On the contrary, the opinion expanded the set of special protections it would hold unconstitutional beyond those involved in the case at hand, suggesting that all laws protecting "labor organizing activities" violate the First Amendment unless they extend the same protections to "other expressive activity."22 Even more strikingly, the D.C. Circuit declined to weigh the California law's objectives against its supposed speech restrictions or, indeed, to consider the law's purpose at all. The mere fact that the law discriminated on the basis of content was enough to render it unconstitutional.

Taken at face value, the D.C. Circuit's reasoning would seem to invalidate all state laws expanding the rights of nonemployee organizers. The court did not rely on the fact that the Moscone Act gave union organizers special rights to distribute literature to the public; it suggested that any law permitting "organizing activities" at private workplaces would be content-discriminatory, and thus unconstitutional, unless it granted the same rights to the public at large. Under this logic, even a law that granted union organizers access to workplaces in order to discuss the benefits of joining a union with employees would raise First Amendment concerns. Waremart II thus appears to constitutionalize the Supreme Court's holding in Lechmere, and to close off the states' ability to extend organizing rights beyond the level set by the NLRA.

18. 599 P.2d 676 (Cal. 1979).

19. Waremart Foods v. NLRB (Waremart II), 354 F.3d 870, 874 (D.C. Cir. 2004).

20. Id. at 875 (citing Carey v. Brown, 447 U.S. 455, 466 (1980); and Police Dep't v. Mosley, 408 U.S. $92,95(1972))$.

21. $I d$.

22. Id. 
Indeed, read for all it is worth, Waremart II does even more than this: It also calls into question the constitutionality of the NLRA itself. After all, Lechmere took away organizing rights only from nonemployee organizers, leaving intact the settled doctrine that, under the NLRA, employees are guaranteed free access to speak and distribute literature about union activities during nonworking time and in nonworking areas. ${ }^{23}$ An employee seeking to communicate with coworkers on topics other than unionization, however-views on a political candidate, ${ }^{24}$ for instance, or a taste for pornography $^{25}$ - can be restricted from doing so. Thus, the NLRA discriminates in favor of union-related speech on the basis of its contentand would therefore appear to be unconstitutional under the sweeping logic of Waremart II.

Of course, the D.C. Circuit did not intend to challenge the constitutionality of the NLRA. That its reasoning does, however, points to the necessity of finding narrower ways to analyze the constitutionality of state right-to-organize laws.

To begin with, Mosley and Carey need not have controlled Waremart II. Both cases involved city ordinances exempting labor organizations from general prohibitions against demonstrating on public sidewalks-in Mosley, sidewalks in front of schools during school hours, and in Carey, sidewalks in front of private residences. The Moscone Act could easily have been distinguished on the ground that, in permitting labor-related speech on private property, it does not prohibit other forms of speech as did the ordinances in Mosley and Carey. Indeed, those cases relied on the public forum doctrine-a doctrine that, at least since Hudgens, has been applied only to regulations of speech on public property. ${ }^{26}$

Abandoning the public forum framework would not in itself free the Moscone Act from constitutional doubt. There are certainly some limits on the ability of state governments to favor certain types of speech over others on private property. For example, a law permitting demonstrations in private supermarket parking lots, but only if the demonstrations concerned

23. See StePHEN I. SCHLOSSBERG \& JUDITH A. SCOTT, ORgANIZING AND THE LAW 52-53 (4th ed. 1991).

24. Cf. Gill v. Farm Bureau Life Ins. Co. of Mo., 906 F.2d 1265 (8th Cir. 1990) (holding that an employer could legally fire a worker for supporting a particular congressional candidate).

25. Cf. Robinson v. Jacksonville Shipyards, Inc., 760 F. Supp. 1486 (M.D. Fla. 1991) (granting an injunction against the display of pornography in a workplace in response to a hostile work environment claim).

26. See, e.g., Good News Club v. Milford Cent. Sch., 533 U.S. 98, 106-07 (2001); Cornelius v. NAACP Legal Def. \& Educ. Fund, Inc., 473 U.S. 788, 800 (1985); Perry Educ. Ass'n v. Perry Local Educators' Ass'n, 460 U.S. 37 (1983). 
environmental issues, would seem to raise serious First Amendment problems. ${ }^{27}$ The hard questions, obscured by the D.C. Circuit's sweeping reasoning, are what distinguishes such a law from ordinary labor laws such as the NLRA, and on which side of the First Amendment line the Moscone Act falls.

One way of making this distinction would be to borrow from public forum reasoning and treat laws opening up private property to public demonstrations as creating "limited public fora." When Mosley and Carey were decided, public forum analysis was still in its infancy, ${ }^{28}$ and the opinions did not distinguish among the three contemporary categories: traditional public fora, limited public fora, and nonpublic fora. ${ }^{29}$ However, in finding content discrimination to be virtually dispositive of unconstitutionality, these cases appear to fit best within the "traditional public forum" category, for only there must content-discriminatory speech regulations undergo strict scrutiny. ${ }^{30}$ Indeed, the Carey Court explained its decision by reciting the canonical formulation of the traditional public forum: "Wherever the title of streets and parks may rest, they have immemorially been held in trust for the use of the public and, time out of mind, have been used for purposes of assembly, communicating thoughts between citizens, and discussing public questions.","31

Unlike streets and parks, private workplaces are hardly traditional venues for free speech. Laws opening up workplaces to public demonstrations are better seen as creating limited public fora, where content-discriminatory laws are analyzed more deferentially. "When the State establishes a limited public forum, the State is not required to and does not allow persons to engage in every type of speech. The State may be justified 'in reserving [its forum] for certain groups or for the discussion of certain topics." "32 As applied to public property, the limited public forum doctrine has received a great deal of criticism as being underprotective of speech $^{33}$ and underdeterminative of constitutionality. ${ }^{34}$ The chief problem

27. I thank Nathan Newman of the Brennan Center for Justice at N.Y.U. for this hypothetical.

28. Indeed, Mosley was the first case in which a majority of the Court adopted the phrase. See Robert C. Post, Between Governance and Management: The History and Theory of the Public Forum, 34 UCLA L. REV. 1713, 1731 (1987).

29. See, e.g., Cornelius, 473 U.S. at 802 (describing these three categories).

30. Content-discriminatory laws are never per se unconstitutional, even in traditional public fora. They are merely subject to heightened scrutiny, and are sometimes upheld. See, e.g., Burson v. Freeman, 504 U.S. 191, 198 (1992) (finding a compelling state interest in banning campaign solicitation within a polling place).

31. Carey v. Brown, 447 U.S. 455, 460 (1980) (quoting Hague v. CIO, 307 U.S. 496, 515 (1939) (Roberts, J.)).

32. Good News Club v. Milford Cent. Sch., 533 U.S. 98, 106 (2001) (quoting Rosenberger v. Rector \& Visitors of Univ. of Va., 515 U.S. 819, 829 (1995)) (alteration in original).

33. See, e.g., Post, supra note 28, at 1745-58.

34. See, e.g., Frederick Schauer, The Supreme Court, 1997 Term-Comment: Principles, Institutions, and the First Amendment, 112 HARV. L. REV. 84, 98-99 (1998). 
seems to be that if the scope of speech allowed in a limited public forum is determined by the purposes for which the state opens it up, it is difficult to see how a state's assertion that a particular form of speech is beyond the scope of the forum can be challenged. ${ }^{35}$ In the case of a regulation that opens up private property for public speech, however, this problem seems less severe. Unlike public property, which governments often control by managerial authority, private property will ordinarily be opened up for speech by statute. Determining whether statutes accord with First Amendment principles is more straightforward than discerning whether a government has managed its property constitutionally. ${ }^{36}$

Analyzing the Moscone Act in light of limited public forum principles would have focused attention on the real issues at stake in Waremart II. Laws regulating speech in limited public fora "must not discriminate against speech on the basis of viewpoint" and "must be "reasonable in light of the purpose served by the forum." to be viewpoint-discriminatory. In protecting the right to leaflet concerning a labor dispute, the law seems to guarantee the rights of workers opposing union campaigns, as well as those supporting them, to make their views known; of course, it also does not prevent management from using its own property to speak out against unions. More importantly, the law does not permit anyone to leaflet about labor issues on private property unless they are involved in a labor dispute with the property owner. Thus, expressing a particular viewpoint regarding a labor dispute is neither a necessary nor a sufficient condition for enjoying the Moscone Act's protections. ${ }^{38}$ This suggests that the Act's purpose is not to favor people expressing prolabor political views. Instead, the purpose of the law seems to be to provide labor with a legal resource that can be used to augment its power vis-à-vis management. ${ }^{39}$ In short, the Moscone Act is a bona fide labor regulation. To treat it as viewpoint-discriminatory and therefore presumptively unconstitutional would be to subvert the post-Lochner tradition of constitutional deference to economic regulations.

35. See Post, supra note 28, at 1757. Despite Post's dire account, challenges to speech restrictions in limited public fora have frequently succeeded. See, e.g., Good News Club, 533 U.S. 98; see also id. at 107 (citing cases).

36. See Post, supra note 28 , at $1782-84$.

37. Good News Club, 533 U.S. at 106-07 (quoting Cornelius v. NAACP Legal Def. \& Educ. Fund, Inc., 473 U.S. 788, 806 (1985)).

38. In contrast, in the case of the hypothetical law permitting environmental demonstrations in supermarket parking lots, expressing a proenvironment viewpoint is a sufficient condition for enjoying the law's protection.

39. See CAL. CIV. PROC. CODE $\$ 527.3$ (a) (West 1979) (stating that the purpose of the statute is "to promote the rights of workers to engage in concerted activities for the purpose of collective bargaining, picketing or other mutual aid or protection"). For an argument that the absence of speech-discriminatory purpose should be dispositive of constitutionality under the First Amendment, see Jed Rubenfeld, The First Amendment's Purpose, 53 STAN. L. REV. 767 (2001). 
The Moscone Act's character as a labor regulation also speaks to its reasonableness in light of the purposes of the private property. At first blush, the Act seems troubling on this score. In Waremart II, the union members were handing out leaflets to the general public calling for consumers to boycott the store. It is not immediately obvious that publicly urging boycotts is a reasonable use of someone else's private property. However, the targeting of nonunionized stores by unions is an established organizing tactic, ${ }^{40}$ and one that is explicitly countenanced by the NLRA. ${ }^{41}$ Furthermore, existing law defines the term "labor dispute" used in the Moscone Act as including boycotts of rival, nonunionized shops, provided the nonunionized shops are in the same industry. ${ }^{42}$ Given that the Moscone Act facilitates the ability of unions to employ established organizing tactics, the Act would seem to be as reasonable as other laws, such as the NLRA, that protect those same tactics.

Even if the facts of Waremart II leave residual First Amendment doubts, the D.C. Circuit's sweeping indictment of laws giving special protection to "organizing activities" is unwarranted. Laws permitting union organizers to speak to employees should probably not be seen as creating public fora of any sort-limited or otherwise--or, indeed, as implicating the First Amendment at all. Instead, they should be treated as the ordinary economic regulations that they are and subjected only to deferential rational basis review. In any case, even under a limited public forum analysis, such ordinary right-to-organize laws would clearly be reasonable in light of the purposes of workplaces. To say otherwise would be to deny the legitimacy of labor unionism. It is a fundamental premise of modern labor law that seeking to form unions is an appropriate use of workplaces, and it is a commonplace of post-Lochner constitutional law that regulations allowing people to do so are presumptively constitutional.

-Aron Fischer

40. See Richard B. Peterson et al., Strategies and Tactics in Union Organizing Campaigns, 31 INDUS. REL. 370, 374 (1992).

41. National Labor Relations Act $\S 8(b)(7)(C), 29$ U.S.C. $\S 158(b)(7)(C)(2000)$ ("[N]othing in this subparagraph $(C)$ shall be construed to prohibit any picketing or other publicity for the purpose of truthfully advising the public (including consumers) that an employer does not employ members of, or have a contract with, a labor organization ....").

42. See Beverly Hills Foodland, Inc. v. United Food \& Commercial Workers Union, Local 655 , 39 F.3d 191, 195 (8th Cir. 1994) ("'A union picketing or boycotting a business which it has not tried to organize (and in some cases cannot organize) nevertheless involves a labor dispute."' (quoting Aarco, Inc. v. Baynes, 462 N.E.2d 1107, 1110 n.3 (Mass. 1984))). 